\title{
ANALISA KAPASITAS TAMPUNG SALURAN DRAINASE AKIBAT PENGARUH LIMPASAN PERMUKAAN KECAMATAN KOTA SUMENEP
}

\author{
Eva Resmani $^{1}$, Ussy Andawayanti ${ }^{2}$, Evi Nur Cahya ${ }^{2}$ \\ ${ }^{1}$ Staf Dinas PU. Sumber Daya Air, Kabupaten Sumenep, Sumenep \\ ${ }^{2}$ Dosen Jurusan Teknik Pengairan, Fakultas Teknik, Universitas Brawijaya, Malang \\ Email : resmani.eva@gmail.com
}

\begin{abstract}
ABSTRAK: Perubahan alih fungsi lahan dari lahan hijau menjadi lahan pemukiman pada menyebabkan terjadinya limpasan permukaan di beberapa lokasi di Kota Sumenep. Kondisi eksisting saluran membutuhkan perubahan dimensi yang mampu menyalurkan limpasan yang terjadi. Penelitian ini bertujuan untuk mengetahui kapasitas saluran drainase yang ada (eksisting) terhadap curah hujan dengan debit rencana kala ulang 5 tahun dan menentukan pengendalian banjir yang dapat dilakukan di Kota Sumenep. Pemodelan dengan SWMM membandingkan kondisi jaringan drainase sebelum dan sesudah penerapan rehabilitasi saluran. Pada perhitungan kalibrasi model diperoleh nilai RMSE sebesar 0,139. Nilai tersebut menunjukkan bahwa nilai parameter yang digunakan dalam pemodelan mendekati variasi nilai observasi. Dari hasil perhitungan diperoleh kapasitas outlet $1=3,53 \mathrm{~m} 3 / \mathrm{dt}$; outlet $2=2,75 \mathrm{~m} 3 / \mathrm{dt}$; outlet $3=2,52$ $\mathrm{m} 3 / \mathrm{dt}$; outlet $4=1,21 \mathrm{~m} 3 / \mathrm{dt}$; outlet $5=4,65 \mathrm{~m} 3 / \mathrm{dt}$; outlet $6=6,20 \mathrm{~m} 3 / \mathrm{dt}$; outlet $7=1,47 \mathrm{~m} 3 / \mathrm{dt}$; outlet $8=0,60 \mathrm{~m} 3 / \mathrm{dt}$; outlet $9=4,49 \mathrm{~m} 3 / \mathrm{dt}$. Jaringan drainase sekunder outlet 3 dan $7 \mathrm{mampu}$ menampung limpasan curah hujan, sedangkan untuk jaringan drainase sekunder outlet 1,2, 4, 5, 6 dan 8 tidak mampu menampung curah hujan dengan debit rencana kala ulang 5 tahun. Untuk mengurangi genangan tersebut, dibutuhkan rencana rehabilitasi saluran drainase sekunder pada masing-masing outlet dan alternatif pengalihan debit limpasan. Berdasarkan perbandingan antara tinggi muka air Sungai Marengan dan outlet saluran, outlet 4, 5, dan 6 mengalami arus balik (backwater) dari Sungai Marengan. Dimensi saluran baru yang telah direncanakan tidak hanya mampu menampung limpasan air hujan, tapi juga mampu menampung limpasan debit akibat dari pengaruh arus balik.
\end{abstract}

Kata kunci: debit limpasan hujan, kapasitas saluran drainasi, SWMM

ABSTRACT : A change in land use of green land into residential land in recent years has caused a runoff in several locations in the Sumenep city. Existing conditions require changes in dimensional channel which is capable of channeling the runoff that has occurred. This study aims to determine the capacity of the existing drainage channels towards the rainfall with 5-year flood discharge plan and determine the flood control that can be performed in the Sumenep city. Modeling using SWMM instrument by comparing the drainage channel conditions before and after the implementation of channel rehabilitation. From the model calibration calculation, the RMSE value obtained is at 0,139. This value indicates that the value of the parameters used in the modeling approaches the observed values variation. From the calculation it is obtained that the first outlet capacity $=3,53 \mathrm{cms} ; 2$ d outlet $=2,75 \mathrm{cms} ; 3 \mathrm{rd}$ outlet $=2,52 \mathrm{cms} ;$; th outlet $=$ $1,21 \mathrm{cms} ; 5$ th outlet $=4,65 \mathrm{cms} ; 6$ th outlet $=6,20 \mathrm{cms} ; 7$ th outlet $=1,47 \mathrm{cms} ; 8$ th outlet $=0,60$ cms; 9 th outlet $9=4,49 \mathrm{cms}$. Secondary drainage channels of outlets 3 and 7 can accommodate the runoff of rainfall, while the secondary outlet for drainage channels of 1,2, 4, 5, 6 and 8 are not capable to accommodate rainfall with the 5-year flood discharge plan. To reduce surface runoff inundation that has happened, it takes a secondary drainage canal rehabilitation plan at each outlet and alternative diversion of runoff discharge. Based on the comparison between the water level of Marengan river and drainage channels outlet, there are reverse flows effect (backwater) in the outlet 4, 5, and 6 from Marengan River. The dimensions of the new planned 
channel is not only capable to accommodate rainwater runoff, but is also capable to accommodate runoff discharge performance due to the reverse flow.

Keywords : runoff, capacity of drainage channels , SWMM

Beberapa lahan yang diperuntukkan sebagai lahan hijau sebagian beralih fungsi menjadi lahan pemukiman sebagai dampak dari perkembangan pembangunan perkotaan. Di mana para pihak pengembang hampir tidak pernah melakukan kajian terhadap resapan di lahan pemukiman tersebut. Dimensi saluran yang ada tidak mampu menampung terjadinya limpasan permukaan. Sehingga mengganggu sistem drainase.

Adapun permasalahan yang terjadi pada daerah studi yaitu, terjadinya limpasan permukaan akibat dari perubahan alih fungsi lahan dari lahan hijau menjadi lahan pemukiman pada beberapa tahun terakhir sehingga menyebabkan beberapa ruas saluran drainasi eksisiting tidak mampu menyalurkan limpasan yang terjadi.

Tujuan yang ingin dicapai pada penelian ini adalah untuk mengetahui kapasitas saluran drainase yang ada (eksisting) terhadap curah hujan dengan debit rencana kala ulang 5 tahun dan menentukan pengendalian banjir yang dapat dilakukan pada daerah kajian.

\section{METODE PENELITIAN}

\section{Data Yang Digunakan}

Daerah studi yang terdapat dalam kecamatan Kota Sumenep adalah wilayah yang cukup strategis karena merupakan ibukota Kabupaten Sumenep (Gambar 1).

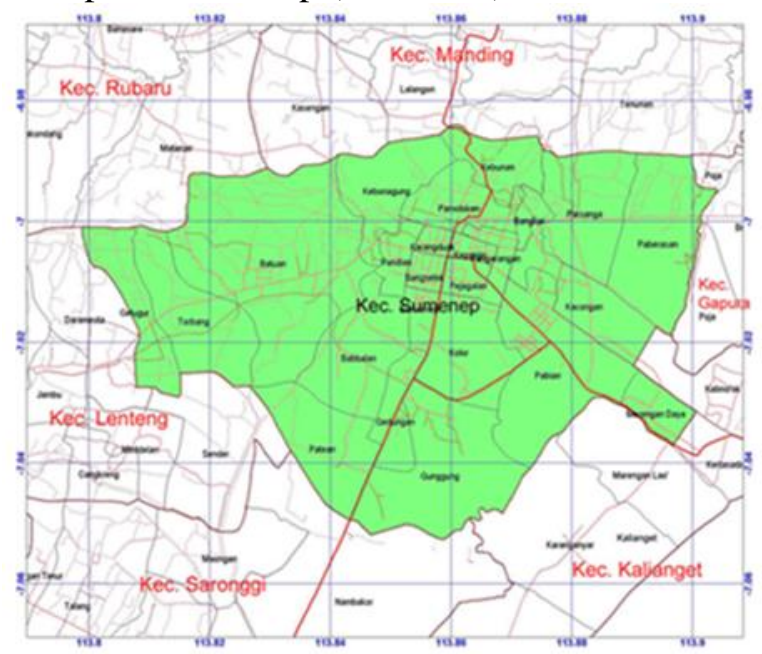

Gambar 1. Daerah studi Kecamatan Kota Sumenep
Kecamatan Kota Sumenep mempunyai 12 desa dan 4 kelurahan dengan luas wilayah 27,84 Km2, merupakan daerah yang mempunyai nilai ekonomi yang tinggi karena fasilitas pemerintahan dan penunjang lainnya sebagian besar ada di wilayah ini. Secara geografis wilayah Kabupaten Sumenep terletak pada koordinat $4^{\circ} 55^{\prime} 00^{\prime}$ " lintang selatan sampai dengan $116^{\circ} 16^{\prime} 48^{\prime \prime}$. Berdasarkan Kecamatan Dalam Angka Kecamatan Kota Sumenep 2016, jumlah penduduk di Kecamatan Kota Sumenep pada tahun 2015 sebesar 69.979 jiwa dengan pertumbuhan sebesar 0,52 persen.

Terdapat tiga stasiun curah hujan yang berada di sekitar lokasi studi yaitu Stasiun Kebonagung, Parsanga, dan Pengairan. Data curah hujan harian 10 tahun yaitu dari tahun 2006 sampai dengan tahun 2015. Letak ketiga stasiun hujan tersebut dalam dilihat pada Gambar 2.

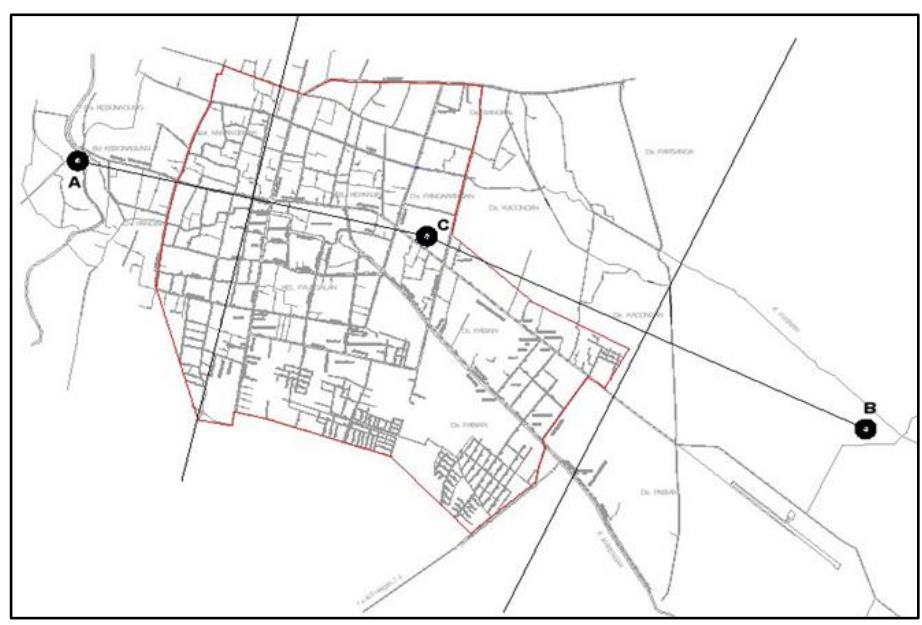

Keterangan :

A Stasiun Kebonagung

B Stasiun Parsanga

C Stasiun Pengairan

Gambar 2. Letak stasiun hujan di Kecamatan Kota Sumenep

Data-data penunjang lainnya yang diperlukan dalam studi ini adalah : peta topografi, peta tata guna lahan, skema jaringan saluran drainase, data saluran drainase eksisting, data curah hujan, data jumlah 
penduduk dan data geometri Sungai Marengan sebagai analisa pada buangan akhir.

\section{Tahapan Analisis}

Secara garis besar tahapan analisa pada penelitian ini terdiri dari : analisa hidrologi, analisa debit air kotor, analisa debit rencana berdasarkan periode ulang 5 tahun dengan menggunakan program SWMM (Strorm Water Management Model), kalibrasi model dengan menggunakan metode Root Mean Square Errors (RMSE), dan analisa buangan akhir.

Pada penelitian ini hujan rancangan dipilih cara Log Pearson III (Soemarto, CD, 1995:125), dengan pertimbangan bahwa cara ini lebih fleksibel dan dapat dipakai untuk semua sebaran data.

$$
\log x=\overline{\log x_{i}}+G \cdot S d
$$

Dengan :

$$
\begin{aligned}
& \mathrm{x}= \begin{array}{l}
\text { curah hujan rancangan dengan kala } \\
\text { ulang tertentu }
\end{array} \\
& \mathrm{x}_{\mathrm{i}}= \begin{array}{l}
\text { curah hujan maksimum daerah } \\
\text { sebanyak } \mathrm{n} \text { buah } \mathrm{X}_{1}, \mathrm{X}_{2}, \mathrm{X}_{3}, \ldots ., \mathrm{X}_{\mathrm{n}}
\end{array} \\
& \mathrm{G}= \begin{array}{l}
\text { merupakan konstanta yang } \\
\text { didapatkan dari tabel Log Pearson }
\end{array} \\
& \begin{array}{l}
\text { Type III dari hubungan antara Cs } \\
\text { dan periode ulang }(\mathrm{T}) .
\end{array} \\
& \mathrm{Sd}= \text { simpangan baku } \\
& \mathrm{Uji} \text { Chi-Square dan Uji Smirnov- }
\end{aligned}
$$

Kolmogorov digunakan untuk menentukan apakah persamaan distribusi yang dipilih dapat mewakili distribusi statistik sampel data yang akan dianalisis. Persamaan X2 hitung pada uji Chi Square dengan rumus (Soewarno,1995;194) :

$$
X^{2}=\sum_{i=1}^{n} \frac{O j-E j}{E j}
$$

Nilai $\mathrm{X}^{2}{ }_{\text {kritis }}$ diperoleh melalui tabel ChiSquare. Apabila $X^{2}{ }_{\text {hitung }}<X^{2}$ kritis maka analisa distribusi curah hujan pengamatan sesuai dengan model teoritis.

Uji Smirnov - Kolmogorov dilakukan untuk mengetahui simpangan horisontal tersebar sebaran teoritis dan sebaran empiris. Simpangan horisontal ini dinyatakan dengan $\Delta$ maks $<\Delta$ cr untuk derajat nyata tertentu, disimpulkan hipotesa distribusi dapat diterima. Persamaan $\Delta$ maks pada uji Smirnov Kolmogorov (Sri Harto,1981:179) :

$$
\Delta \text { maks }=|\mathrm{Pe}-\mathrm{Pt}|
$$

$\Delta$ maks $=$ selisih maksimum antara peluang empiris dan teoritis

$\mathrm{Pe} \quad=$ peluang empiris

$\mathrm{Pt} \quad=$ peluang teoritis

$\Delta \mathrm{cr} \quad=$ simpangan kritis (dari tabel)

Distribusi frekuensi yang dipilih dapat diterima apabila $\Delta_{\text {maks }}<\Delta$ cr dan terjadi sebaliknya jika $\Delta_{\text {maks }}>\Delta \mathrm{cr}$

Analisa Intensitas Durasi dan Frekuensi (IDF) dilakukan untuk memperkirakan debit puncak di daerah tangkapan kecil (Triatmodjo, B. 2006), menggunakan rumus Mononobe sebagai berikut :

$I=\frac{R_{24}}{24}\left[\frac{24}{t_{c}}\right]^{2 / 3}$

dengan :

$\mathrm{I}=$ intensitas hujan selama waktu konsentrasi ( $\mathrm{mm} / \mathrm{jam})$

R24 = curah hujan maksimum harian

Debit air kotor adalah debit yang berasal dari buangan rumah tangga, bangunan gedung, instansi dan sebagainya. Besarnya dipengaruhi oleh banyaknya jumlah penduduk dan kebutuhan air rata-rata penduduk. Adapun besarnya kebutuhan air penduduk rata-rata adalah 150 liter/orang/hari. Sedangkan debit air kotor yang harus dibuang di dalam saluran adalah $70 \%$ dari kebutuhan air bersih sehingga besarnya air buangan adalah (Suhardjono, 1984:39): $150 \times 70 \%=105$ liter/orang/hari = 0,00121 liter/dtk/orang.

Untuk jumlah penduduk sebesar (Pn), maka air kotor yang dibuang setiap km2 dapat dihitung sebagai berikut :

$\mathrm{Qak}=(\mathrm{Pn} . \mathrm{q}) / \mathrm{A}$

dengan :

Qak = debit air kotor (liter $\left./ \mathrm{dtk} / \mathrm{km}^{2}\right)$

$\mathrm{Pn}=$ jumlah penduduk (jiwa)

$\mathrm{q}=$ jumlah air buangan (liter/dtk/orang)

$\mathrm{A}=$ luas daerah $\left(\mathrm{km}^{2}\right)$

Untuk menghitung debit banjir rancangan digunakan software SWMM dikembangkan oleh EPA (Environmental Protection Agency USA), sejak 1971. SWMM tergolong model hujan aliran dinamis yang digunakan untuk simulasi dengan rentang waktu yang menerus atau kejadian banjir sesaat. Model ini paling banyak dikembangkan untuk simulasi proses hidrologi dan hidrolika di wilayah perkotaan. 
Dengan menggunakan SWMM, kondisi yang terjadi di lapangan dapat dimodelkan dengan memasukkan parameter-parameter yang tercatat pada kondisi sesungguhnya.

Analisa buangan akhir dilakukan untuk mengetahui adanya pengaruh arus balik (backwater) dari sungai ke saluran. Dengan membandingkan tinggi muka air di sungai dan saluran. Jika tinggi muka air di sungai lebih tinggi dari tinggi muka air di saluran, maka dilakukan perhitungan pengaruh air balik di saluran. Namun jika tinggi muka air saluran lebih tinggi dari tinggi muka air sungai maka tidak perlu dilakukan perhitungan pengaruh air balik. Analisa ini menggunakan Metode Tahapan Langsung (Direct Step Method) dengan menggunakan persamaan (Chow, V. T. 1997) :

$\Delta x=\frac{\left(y_{2}+\frac{V_{2}^{2}}{2 g}\right)-\left(y_{1}+\frac{V_{1}^{2}}{2 g}\right)}{I_{o}-I_{f}}$

\section{HASIL DAN PEMBAHASAN}

Untuk melengkapi data yang hilang atau rusak diperlukan data dari stasiun lain yang memiliki data yang lengkap dan diusahakan letak stasiunnya paling dekat dengan stasiun yang hilang datanya. Dari hasil perhitungan data curah hujan maksimum stasiun hujan Pengairan $64 \mathrm{~mm}$ pada tahun 2007 dan data total curah hujan stasiun Pengairan $1.274 \mathrm{~mm}$ pada tahun 2007.

Untuk memastikan data hujan yang ada tersebut layak digunakan pada analisa selanjutnya, maka data yang sudah ada tersebut dilakukan uji statistik. Analisa statistik tersebut meliputi : uji konsistensi, uji ketiadaan trend, uji stasioner dan uji persistensi.

Dari hasil uji konsistensi dapat disimpulkan bahwa data hujan pada ketiga stasiun penakar hujan tersebut konsisten yang berarti bahwa pada daerah pengaruh stasiun tersebut tidak terjadi perubahan lingkungan dan tidak terjadi perubahan cara menakar selama pencatatan data tersebut.

Pada uji ketiadaan trend, data hujan pada masing-masing stasiun dilakukan uji ketiadaan trend. Deret berkala dua seri data (Rt dab $\mathrm{Tt}$ ) adalah independent pada derajat kepercayaan $5 \%$. Dan $\mathrm{dk}=10-2=8$, maka diperoleh nilai $\mathrm{t}_{\mathrm{c}}$ sebesar 1,860. Dari hasil perhitungan diperoleh $t_{\text {hitung }}$ untuk masing-masing stasiun hujan Kebonagung, Parsanga, dan Pengairan sebesar : $-0,189 ; 0,688$; dan 0,363 , maka $t_{\text {hitung }}$ $<\mathrm{t}_{\mathrm{c}}$. Selain dengan perhitungan uji $-\mathrm{t}$, ketiadaan trend dapat juga ditentukan dengan menggambarkan deret berkala dalam grafik (Gambar 3 - 5). Dengan demikian dapat disimpulkan bahwa data hujan pada periode tahun 2006 - 2015 yang tercatat pada ketiga stasiun tersebut tidak mempunyai kecenderungan menuju ke satu arah, arah naik atau menurun (trend).

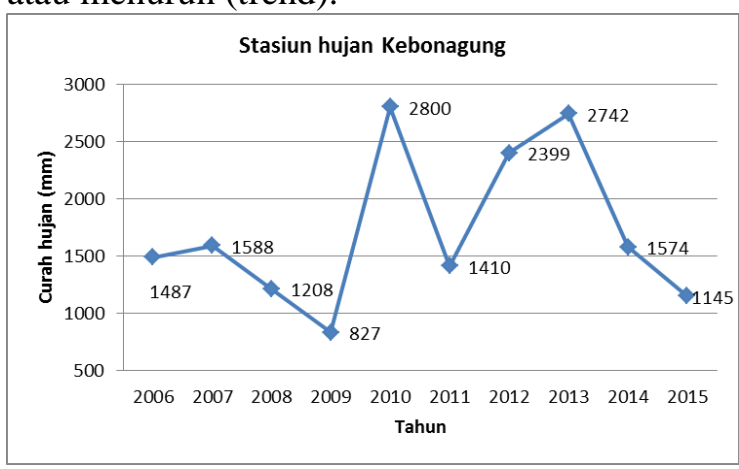

Gambar 3. Deret berkala data curah hujan stasiun Kebonagung tahun 2006 - 2015

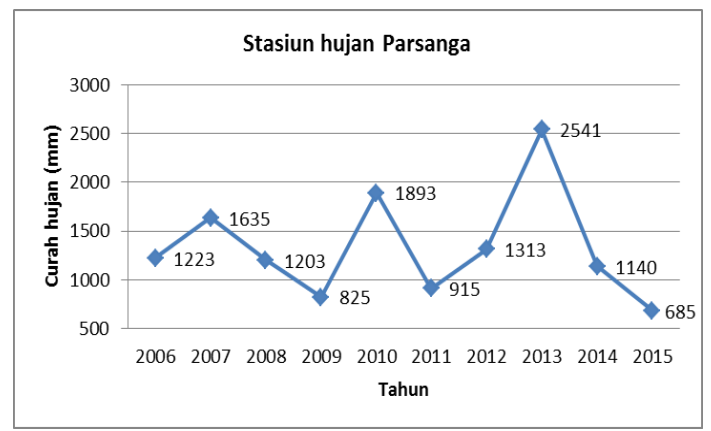

Gambar 4. Deret berkala data curah hujan stasiun Parsanga tahun 2006 - 2015

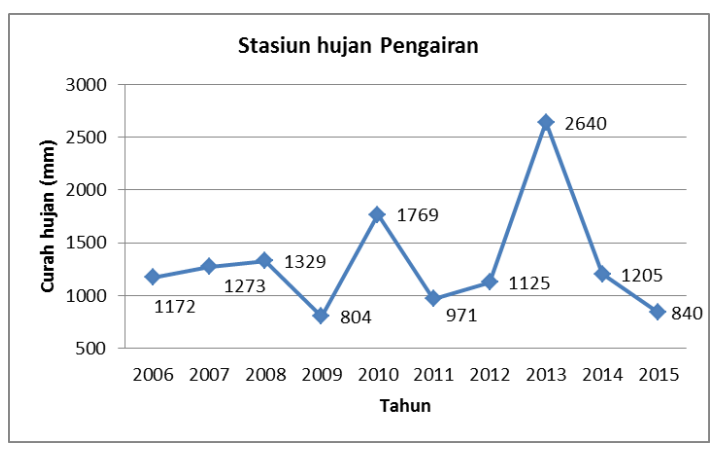

Gambar 5. Deret berkala data curah hujan stasiun Pengairan tahun 2006 - 2015

Dalam uji stasioner ini data dibagi menjadi dua kelompok, sehingga data hujan pada lokasi studi dibagi menjadi Kelompok I untuk periode hujan tahunan 2006 - 2010 dan 
Kelompok II untuk periode hujan tahunan $2011-2015$.

- Uji kestabilan varian

Diperoleh F untuk masing-masing data hujan stasiun Kebonagung, Parsanga dan Pengairan adalah 1,182;0,330; dan 0,224, sedangkan nilai $\mathrm{F}_{\text {kritis }}=6,39$, maka $\mathrm{F}_{\text {kritis }}>\mathrm{F}_{\text {hitung. }}$. Sehingga disimpulkan bahwa data hujan pada stasiun tersebut berdasarkan uji kestabilan varian adalah stasioner atau homogen.

- Uji kestabilan rata-rata

Diperoleh $\sigma$ dan $t$ untuk masing-masing data hujan stasiun Kebonagung, Parsanga dan Pengairan adalah 797,08 dan $(-0,54) ; 659,13$ dan 0,$09 ; 639,72$ dan $(-0,21)$. Sedangkan nilai $\mathrm{t}_{\text {kritis }}$ untuk $\mathrm{dk}=8$ diperoleh nilai 1,860 maka $\mathrm{t}_{\text {kritis }}>\mathrm{t}_{\text {hitung. }}$. Sehingga disimpulkan bahwa data hujan adalah stasioner.

Pada uji persistensi, diperoleh nilai KS dan t. Dengan $\mathrm{dk}=8$ maka diperoleh $\mathrm{t}_{\text {kritis }}=$ 1,86. Dari hasil analisa uji persistensi dimana nilai $t_{\text {kritis }}>t_{\text {hitung }}$ maka dapat disimpulkan bahwa data hujan yang tersedia adalah independen atau tidak menunjukkan adanya persistensi. Atau dapat dikatakan bahwa data tersebut merupakan data bersifat acak.

Besarnya curah hujan maksimum rata-rata daerah diperoleh dengan menggunakan data dari 2 (dua) stasiun penakar hujan yang berpengaruh, yaitu: Stasiun Kebonagung dan Stasiun Pengairan. Periode pengamatan data curah hujan yang digunakan selama 10 (sepuluh) tahun dari tahun 2006 s/d 2015. Perhitungan hujan rata rata dilakukan dengan menggunakan cara aritmatik. Dari perhitungan diperoleh kedalaman hujan tertinggi adalah sebesar $131 \mathrm{~mm}$, terendah $57 \mathrm{~mm}$ dan rata rata sebesar $82 \mathrm{~mm}$. Dari tahapan perhitungan curah hujan rancangan Log Pearson Type III, didapat curah hujan rancangan kala ulang 5 tahun sebesar 97,84 mm.

Dengan menggunakan persamaan Mononobe hujan deras dengan durasi singkat dapat diperoleh. Hitungan dilakukan dengan durasi sampai 300 menit (5 jam). Besaran kedalaman hujan periode 5 tahun dengan durasi 1-5 jam menjadi parameter masukan hujan pada simulasi SWMM (Tabel 1).
Tabel 1. Curah Hujan Rancangan

\begin{tabular}{cc}
\hline $\begin{array}{c}\text { Durasi } \\
\text { (menit) }\end{array}$ & $\begin{array}{c}\text { Periode Ulang } \\
5 \text { tahun }\end{array}$ \\
\hline 60 & 33,92 \\
120 & 21,37 \\
180 & 16,31 \\
240 & 13,46 \\
300 & 11,60 \\
\hline
\end{tabular}

Sumber : Hasil perhitungan

Berdasarkan peta sub DAS Sungai Marengan, sistem drainase eksisting dibagi menjadi 8 titik outlet. Titik outlet diurut berdasarkan letak posisi elevasi tertinggi diukur dari hulu sungai Marengan. Berikut ini uraiannya:

1. Outlet 1. Jaringan drainase sekunder ini melewati jalan Dipenogoro - Jenderal Sudirman - Ahmad Yani.

2. Outlet 2. Jaringan drainase sekunder ini melewati jalan Imam Bonjol - KH. Agus Salim, kemudian dari jalan Pahlawan Kartini.

3. Outlet 3. Jaringan drainase sekunder ini melewati jalan KH. Sajad - Dr. Wahidin.

4. Outlet 4. Jaringan drainase sekunder ini melewati jalan Dr. Cipto.

5. Outlet 5. Jaringan drainase sekunder ini melewati jalan KH. Mansyur - Raung, kemudian dari jalan Urip Sumoharjo (perempatan PLN ke arah timur).

6. Outlet 6. Jaringan drainase sekunder ini melewati jalan Wahid Hasyim - Pasar Anom Sumenep - Perum Bumi Sumekar Perum Satelit.

7. Outlet 7. Berada di jalan Kalimook Marengan Daya.

8. Outlet 8. Berada di Desa Marengan Laok.

Skema eksisting jaringan drainase dapat dilihat pada Gambar 5.

Adapun beberapa data masukan yang dibutuhkan oleh SWMM antara lain :

Input data daerah tangkapan (Subcatchment)

Berikut adalah input data yang dipakai untuk menganalisa debit banjir rencana untuk daerah tangkapan air Kota Sumenep.

a. Batas penentuan sub-DTA (Daerah Tangkapan Air) berdasarkan pada letak saluran sekunder yang disesuaikan dengan arah aliran yang ada dan batasan Sub DAS Marengan.

b. Prosentase impervious (lahan yang kedap air) ditentukan berdasarkan Data Image Google Earth Pro pada tanggal pencitraan 02 Agustus 2016. 
c. Prosentase kemiringan lahan diambil berdasarkan peta kontur DAS Sungai Marengan.

d. Tinggi genangan (depression storage/ds) adalah bagian dari permukaan porus (pervious) dan kedap (impervious) yang terdapat genangan air, sehingga berpotensi menjadi limpasan, yang dinyatakan dalam satuan $\mathrm{mm}$. Nilai ketinggian genangan untuk lahan kedap dan porus bervariatif sesuai dengan kondisi lahan di lapangan. Nilai tinggi genangan pada lahan kedap dapat dibagi menjadi 2 jenis, yaitu : lahan pemukiman 1,27 $\mathrm{mm}$ dan lahan jalan/aspal 2,54 mm. Sedangkan untuk nilai tinggi genangan pada lahan porus dapat dibagi menjadi 3 jenis, yaitu: lahan sawah (pasture) 5,08 mm, lahan tegalan 5,07 $\mathrm{mm}$, dan lahan pekarangan $2,55 \mathrm{~mm}$. e. Infiltrasi adalah suatu proses di mana air hujan merembes masuk ke dalam tanah permukaan pervious subcatchment area. SWMM menyediakan tiga pilihan untuk memodelkan infiltrasi, yaitu persamaan Horton, metode Green - Ampt, dan metode nomor kurva. Analisa ini menggunakan persamaan Horton.

f. Luas daerah tangkapan. Untuk luas subDTA diperoleh dari peta digital dengan menggunakan aplikasi AutoCad.

g. Outlet. Merupakan nama node yang menerima aliran air pada subcatchmen.

h. Lebar daerah tangkapan, diambil berdasarkan lebar daerah tangkapan sebenarnya di lapangan.

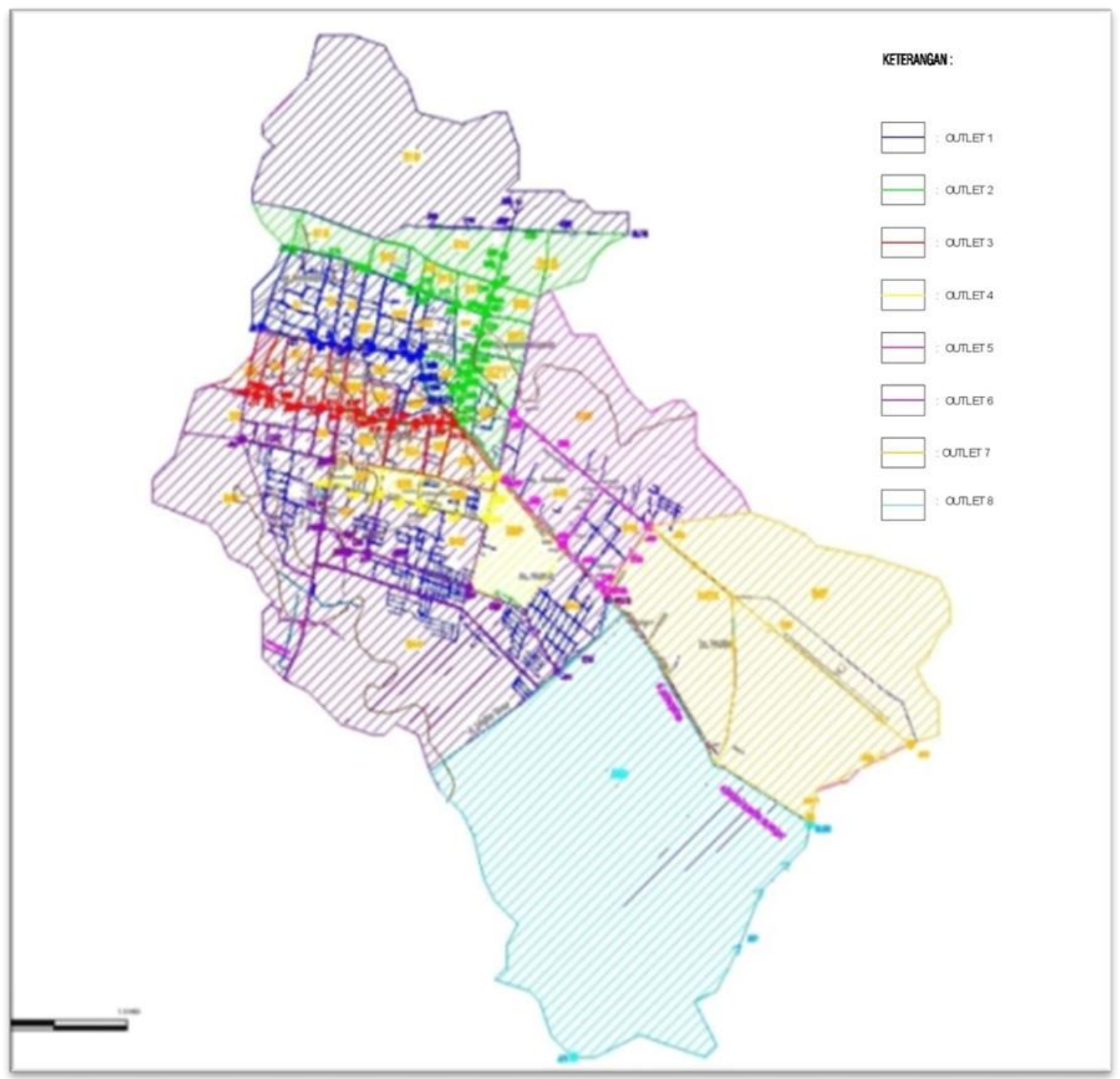

Gambar 6. Peta pembagian outlet sub DAS Marengan 
Conduit adalah penghubung yang mengalirkan air dari suatu node ke node lainnya dalam sistem pengaliran dalam hal ini dapat berupa saluran terbuka maupun tertutup. Penampang melintang saluran dapat ditentukan melalui tabel yang telah disediakan.

Elevasi dasar junction diambil berdasarkan kondisi sebenarnya di lapangan. Sedangkan untuk kedalaman air maksimal diambil berdasarkan tinggi air maksimal pada saluran.

Untuk dapat menghitung debit air kotor dibutuhkan data jumlah penduduk Kota Sumenep. Kemudian data jumlah penduduk tersebut diproyeksikan hingga tahun 2033. Dengan menggunakan persamaan 5 debit air kotor di saluran sekunder dapat dihitung. Debit air kotor yang diperoleh menjadi parameter masukan inflow pada SWMM.

Dari hasil simulasi SWMM, didapat debit banjir rancangan total. Debit tersebut merupakan akumulasi antara debit air kotor dan debit air hujan dari hulu sampai hilir saluran.

Untuk mengukur tingkat akurasi hasil prakiraan suatu model, dilakukan kalibrasi Root Mean Square Error (RMSE). Dari hasil perhitungan perbandingan debit aliran simulasi dan observasi pada saluran C19' (outlet 3) diperoleh nilai RMSE sebesar 0,139. Nilai tersebut menunjukkan bahwa nilai parameter yang digunakan dalam pemodelan mendekati variasi nilai observasi. Dengan membandingkan debit rancangan dan kapasitas saluran eksisting, didapatkan beberapa saluran tidak mampu menampung debit kala ulang 5 tahun. Untuk itu dibutuhkan rehabilitasi saluran drainase. Qrancangan pada tiap saluran menjadi dasar perhitungan dimensi yang baru. Sesuai dengan Peraturan Menteri Pekerjaan Umum Nomor 12/PRT/M/2014 Tentang Penyelenggaraan Sistem Drainase Perkotaan, sarana drainase kapasitasnya minimal $10 \%$ lebih tinggi dari kapasitas rencana saluran. Berdasarkan hal tersebut, debit rancangan yang diperoleh dikalikan dengan 1,1 .

Adapun jaringan drainase yang membutuhkan rehabilitasi antara lain outlet 1 , 2, 4, 5, 6, dan 8 (Tabel 2). Pada outlet 2, selain dilakukan perubahan dimensi, dilakukan pula alternatif pengalihan debit menuju Sungai Patrian. Hal ini mampu menurunkan debit limpasan pada outlet 2 dari yang awalnya sebesar $7,15 \mathrm{~m}^{3} / \mathrm{dt}$ menjadi $2,77 \mathrm{~m}^{3} / \mathrm{dt}$.

Tabel 2. Hasil perhitungan dan evaluasi kapasitas saluran drainase Kec. Kota Sumenep

\begin{tabular}{|c|r|r|c|}
\hline Outlet & $\begin{array}{c}\text { Qkapasitas } \\
\mathrm{m}^{3} / \mathrm{dt}\end{array}$ & $\begin{array}{c}\text { Qrancangan } \\
\mathrm{m}^{3} / \mathrm{dt}\end{array}$ & $\begin{array}{c}\text { Keterangan } \\
\mathrm{m}^{3} / \mathrm{dt}\end{array}$ \\
\hline 1 & 1,96 & 3,53 & Tergenang \\
\hline 2 & 3,78 & 7,15 & Tergenang \\
\hline 3 & 2,88 & 2,52 & Cukup \\
\hline 4 & 0,58 & 1,21 & Tergenang \\
\hline 5 & 0,65 & 4,65 & Tergenang \\
\hline 6 & 2,15 & 6,20 & Tergenang \\
\hline 7 & 1,49 & 1,47 & Cukup \\
\hline 8 & 0,35 & 0,60 & Tergenang \\
\hline
\end{tabular}

Sumber : Hasil Perhitungan

Setelah dilakukan analisa kapasitas tampung dan rehabilitasi saluran, selanjutnya dilakukan analisa buangan akhir di Sungai Marengan. Untuk mengetahui adanya pengaruh aliran balik (backwater) dari sungai ke saluran dengan menggunakan Metode Tahapan Langsung. Terdapat 4 outlet yang berpengaruh terhadap arus balik, yaitu outlet 4 , outlet 5 , outlet 6 , dan outlet 7 , dengan panjang pengaruh aliran balik masing-masing sepanjang : $317,93 \mathrm{~m}, 677,50 \mathrm{~m}, 507,41 \mathrm{~m}$, dan $1.523,41 \mathrm{~m}$. Tinggi muka air pada outlet 4 , outlet 5 , outlet 6 , dan outlet 7 dipengaruhi oleh hujan dengan kala ulang 5 tahun dan pengaruh aliran balik dari sungai. Sehingga pada perhitungan dimensi saluran yang baru, tinggi muka air akibat hujan dengan kala ulang 5 tahun ditambahkan dengan tinggi muka air akibat pengaruh aliran balik dari sungai agar 4 outlet yang terpengaruh aliran balik tersebut mampu menampung hujan dengan kala ulang 5 tahun dan pengaruh aliran balik dari sungai.

\section{KESIMPULAN}

Dari hasil perhitungan pada analisa data dan pembahasan pada bab sebelumnya maka dapat diambil beberapa kesimpulan, antara lain sebagai berikut :

1. Dari hasil perhitungan diperoleh kapasitas outlet $1=3,53 \mathrm{~m}^{3} / \mathrm{dt}$; outlet $2=7,15 \mathrm{~m}^{3} / \mathrm{dt}$; outlet $3=2,52 \mathrm{~m}^{3} / \mathrm{dt}$; outlet $4=1,21 \mathrm{~m}^{3} / \mathrm{dt}$; outlet $5=4,65 \mathrm{~m}^{3} / \mathrm{dt}$; outlet $6=6,20 \mathrm{~m}^{3} / \mathrm{dt}$; outlet $7=1,47 \mathrm{~m}^{3} / \mathrm{dt}$; outlet $8=0,60 \mathrm{~m}^{3} / \mathrm{dt}$. Hanya jaringan drainase sekunder outlet 3 dan 7 yang mampu menampung limpasan curah hujan, sedangkan untuk jaringan drainase sekunder outlet $1,2,4,5,6$ dan 8 tidak mampu menampung curah hujan dengan debit rencana kala ulang 5 tahun. 
Hal ini yang menyebabkan titik genangan terjadi di beberapa ruas jalan. Outlet 7 dipengaruhi oleh arus balik dari Sungai Marengan menuju saluran yang menyebabkan terjadi limpasan pada outlet tersebut. Untuk itu outlet 7 membutuhkan rehabilitasi saluran akibat pengaruh arus balik.

2. Untuk mengurangi genangan akibat limpasan permukaan yang terjadi, dibutuhkan rencana rehabilitasi saluran drainase sekunder pada masing-masing outlet. Sedangkan untuk mengurangi beban debit pada outlet 2, maka digunakan alternatif pengalihan debit ke outlet 9 yang bermuara di Sungai Patrean. Alternatif pengalihan debit ini mampu menurunkan debit limpasan pada outlet 2 yang awalnya sebesar $7,15 \mathrm{~m}^{3} / \mathrm{dt}$ menjadi $2,77 \mathrm{~m}^{3} / \mathrm{dt}$. Berdasarkan perbandingan antara tinggi muka air Sungai Marengan dan outlet saluran, pada outlet 4, 5, dan 6 terjadi pengaruh arus balik (backwater) dari Sungai Marengan menuju outlet saluran. Sedangkan pada outlet 7 setelah dilakukan rehabilitasi saluran, outlet tersebut tidak lagi dipengaruhi oleh arus balik. Dimensi saluran baru yang telah direncanakan tidak hanya mampu menampung limpasan air hujan dengan kala ulang 5 tahun, tapi juga mampu menampung limpasan debit akibat dari pengaruh arus balik dari Sungai Marengan.

\section{SARAN}

Kondisi eksisting wilayah kota bagian selatan masih banyak lahan kosong dan bangunan masih relatif rendah sehingga masih memungkinkan bagi pengembangan fisik kota.
Perkembangan Kota Sumenep bagian selatan akan mengubah lahan pertanian menjadi pemukiman. Hal ini akan merubah koefisien pengaliran (C) lebih tinggi sehingga debit air limpasan lebih banyak mengalir ke saluran. Untuk itu perlu diantisipasi dengan menyediakan saluran drainase yang memadai.

\section{DAFTAR PUSTAKA}
Anonim 2014. Tata Cara Penyusunan Rencana Induk Sistem Drainase Perkotaan (No. 12/PRT/M/2014) Jakarta : Kementerian Pekerjaan Umum.

Badan Standardisasi Nasional. 1994. SNI 033424-1994 Tata Cara Perencanaan Drainase Permukaan Jalan. Jakarta: BSN.

Chow, V. T. 1997. Hidrolika Saluran Terbuka (Ope Channel Hydraulics), Jakarta: Erlangga.

Soehardjono. 1984. Drainasi. Malang: Fakultas Teknik Universitas Brawijaya.

Soemarto, CD. 1995. Hidrologi Teknik. Jakarta: Erlangga.

Soewarno. 202. Hidrologi, Aplikasi Metode Statistk Untuk Analisa Data, Jilid I. Bandung: Nova.

Sri Harto, 1993. Analisis Hidrologi. Jakarta: Gramedia.

Triatmodjo, B. 2006. Hidrologi Terapan. Yogyakarta: Beta Offset Yogyakarta.

United States Environmental Protection Agency. 2010. Storm Water Management Model 5.0 User's Manual. https://www.epa.gov/waterresearch. Diakses tanggal 03 Agustus 2016. 